\title{
Sahib Singh Sokhey (1887-1971): An Eminent Medico-Pharmaceutical Professional
}

\author{
Harkishan Singh*
}

(Received 13 May 2015; revised 27 May 2015)

\begin{abstract}
Major General Sir Sahib Singh Sokhey, an alumnus of the University of Edinburgh, stood first when he appeared for the Indian Medical Service examination. During his stay in Britain, he was very much impressed with the progressive intellectual tradition and gradually got known for his radical views and nationalistic fervour. He spent major part of his professional career as Director of the Haffkine Institute at Bombay. The Institute went through a large growth and consolidation with him at the helm. He was a committed votary of public sector primacy. It was his spadework which later led to creation of the Indian Drugs and Pharmaceuticals Limited. It has been said that he was indeed the father of public sector drug production. He also created awareness for revision of the Patents and Design Act, 1911, that ultimately resulted in the formulation of the Patents Act, 1970, which provided for process patenting. Sokhey had the foresight to create drug testing facilities at the Haffkine Institute; the nucleus so established was the forerunner for organization of drugs testing laboratories in the states of Maharashtra and Gujarat.
\end{abstract}

Key words: Cholera vaccine, Drugs testing laboratories, Haffkine Institute, Hindustan Antibiotics, Indian Drugs \& Pharmaceuticals Limited, Patents Act 1970, Plague vaccine, Public sector drugs production.

\section{INTRODUCTION}

Major General Sir Sahib Singh Sokhey, a medical man by training, contributed handsomely to laying of national policy for public sector drug production, which led to India becoming one of the top producers of drugs in the world. The creation of drug testing facilities also attracted his attention.

As Director of the Haffkine Institute, Sokhey was an able administrator and leader of work force for making the Institute as one of the best medical institutions in the country. There was a large expansion and also consolidation of the existing facilities.

Sahib Singh was happily married to Leila Roy, stage name Menaka, who was renowned in the Kathak and Manipuri style of dancing.

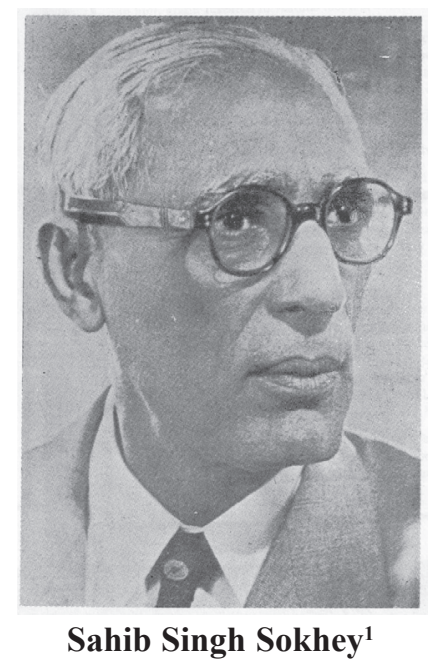

His life history and contributions are covered here under the sections: Early Life and Studies, Entry to the Indian Medical Service and Working as Rockefeller Fellow; Haffkine Institute

\footnotetext{
*Professor Emeritus, Pharmaceutical Sciences, Panjab University, 1135, Sector 43, Chandigarh 160022.

${ }^{1}$ M. L. Ahuja, “Obituary,” Indian Journal of Medical Research, 59 (1971) vii-viii
} 
Directorship and Working with WHO; Crusader for Public Sector Drug Production and Patents Act Revision; Creator of Drug Testing Facilities; and Epilogue.

\section{Early Life and Studies, Entry to the Indian Medical Service and Working as Rockefeller Fellow}

Sahib Singh Sokhey was born on 15 December 1887 at Amritsar. He had his schooling at the Government Central Model School at Lahore, followed by four years of college studies at the Government College, gaining B.Sc. degree in 1907 from the Panjab University. He was student at the Medical College in Lahore before proceeding abroad for education at the University of Edinburgh. His home address at the University was recorded as "The Palms," Shwebo, Burma, India. $^{2}$

In 1911, he graduated from the University for the M.B.,Ch.B. degree. During his course he spent some months at the Western Dispensary, Edinburgh Infirmary and City Hospital.

In 1912, he obtained MA degree from the University. The subjects in his course of study for his Arts degree were Zoology, Mathematics, Sanskrit, Psychology and Political Economy (see foot note 2).

For writing on Sokhey the memoirs prepared by Ganapathi $(1976)^{34}$ and information obtained from the Rockefeller Archive Center ${ }^{5}$ on him proved to be of interest.

Sokhey got Diploma in Tropical Medicine and Hygiene in 1915 from London School of Tropical Medicine. It was many years later subsequent to his graduation from the University of Edinburgh that he earned the M.D. degree in 1925 on his thesis entitled "Ammonia mechanism: An experimental study of the part played by Ammonia, fixed base line and phosphate in the elimination of acid from the body (see footnote 2)."

Sokhey competed for the Indian Medical Service in 1913 and stood first in the examination (Ganapathi,1976, pp. 134-153). As an I.M.S. officer he served in World War I in France and Mesopotamia till 1921. On return to India, he commanded the Indian Military Hospital at Calcutta.

It may be mentioned that while in Britain Sahib Singh was much influenced with the progressive intellectual tradition (Ganapathi, 1976, pp. 134-153). The economic scene and political developments there interested him. The awakening he got left impact on him. This shaped and guided his activities throughout his life.

Sokhey availed of Rockefeller Fellowship during 1923-25 (Ganapathi,1976, pp. 134-153) This enabled him to carry out studies in selected institutions in the United States of America,

\footnotetext{
${ }^{2}$ Special Collection, Edinburgh University Library, University of Edinburgh. Through correspondence dated 18 June 2008 with Irene Ferguson, University Archives Assistant. In reference 4, it has been mentioned that Sahib Singh's father was a civil engineer who was connected with irrigation schemes of the Punjab and Burma. So mention of his home address in Burma is understandable. At the time Burma was a part of India.

${ }^{3}$ Platinum Jubilee Commemoration Volume, Haffkine Institute 1899-1974. Selected pages supplied by Dr S. M. Sapatnekar, Director of the Institute through his letter of 1 November 2002

${ }^{4}$ K. Ganapathi, "Sahib Singh Sokhey, As I knew him," Platinum Jubilee Commemoration Volume, Haffkine Institute $1899-1974$. pp 20-28 Selected pages supplied by Dr S. M. Sapatnekar, Director of the Institute through his letter of 1 November 2002

${ }^{5}$ Rockefeller Foundation Collection, Record Groups 1.1, 6.1, 10.2, Rockefeller Archive Center, Sleepy Hollow, NY; on correspondence with Bethany J. Antos, Archivist \& Internship Program Coordinator, through Dr Pardeep Gupta of the USciences, some useful material has been obtained on Sokhey.

${ }^{6}$ Rockefeller Foundation Collection, Record Groups 1.1, 6.1, 10.2, Rockefeller Archive Center, Sleepy Hollow, NY; on correspondence with Bethany J. Antos, Archivist \& Internship Program Coordinator, through Dr Pardeep Gupta of the USciences, some useful material has been obtained on Sokhey.
} 
Canada, and England from 1923 to 1925 . He had the privilege of working with famous biochemists like Professor Otto Folin of Harvard, Professor J. B. Macleod of Toronto and Professor Frederick Gowland Hopkins of Cambridge. Biochemistry became his field of study. He got to hold the view that it had become practically impossible to practice modern medicine without the aid of biochemical analytical work.

\section{Haffine Institute Directorship and WORKING WITH WHO}

Sahib Singh Sokhey remained Director of the Haffkine Institute for seventeen years. The material on his tenure of directorship has been largely drawn from the writings by Ganapathi (Ganapathi, 1976, pp.134-153).

Sokhey joined the Haffkine Institute in 1925 as Assistant Director. At the time he held the IMS rank of a Major, later becoming Lieut.Colonel. He was put as in-charge of the Biochemistry Department. He also officiated for short periods as Director of the Institute. His permanent appointment as Director came in 1932. He was first Indian to hold the position of director of the Institute.

His initial work was on sprue revealing that anaemia of sprue and of pregnancy had great resemblance to pernicious anaemia (BMJ, 1930, p.616). He started organizing the Biochemistry Department and the problem of plague and improving the plague vaccine became his major task. Haffkine Institute was the centre for manufacture of plague vaccine for whole of India.

At the time when Sokhey took over as Director in 1932, the Government desired to make the Institute self-sufficient by increasing the prices of the products or to submit proposals for winding it up. He replied in the opposite, suggesting reduction in prices of the products and expansion of the Institute. He was able to convince the Government and the Institute continued to function. There was consolidation and expansion of the institution with him at the helm.

There was created Entomology Department in 1938 to undertake field work on the epidemiology of plague. Serum Department was organized in 1940, for producing the tetnus, diphtheria, dysentery and gas gangrene antitoxins; the tetnus and diphtheria toxoids; and the polyvalent antivenin. Chemotherapy Department came up in the same year, about its functioning a coverage is provided in the next section. In 1943 the Pharmacology Department formally became part of the Institute, which till then was maintained by the Indian Research Fund Association. Blood Bank was organized. In 1944, the Nutrition Department was established which later became a part of Public Health Department. Creation of Biophysics Department was envisaged but Sokhey retired before it could take shape.

On a visit to Bangkok once he was much impressed with snake farm there and on return he decided to have a similar farm in the Institute ${ }^{7}$.

His scientific work which started with biochemistry of sprue, was followed by study on micromethods for biochemical analysis as an aid for diagnostic examinations, basal metabolic rates, haemoglobin constants, blood urea nitrogen and urinary nitrogen contents in chemical investigations.

He devoted major portion of his time and efforts on plague and plague vaccine and made important investigations which were of great value to the country. He was acclaimed as a pioneer in immunology of plague. There could be turned out plague vaccine in larger quantities which was of superior protective power and free from toxic reactions. A method for accurate standardization of plague vaccine and measuring of its protective power was developed.

\footnotetext{
${ }^{7}$ B. B. Dixit, Platinum Jubilee Commemoration Volume, Haffkine Institute 1899-1974. Selected pages supplied by Dr S. M. Sapatnekar, Director of the Institute through his letter of 1 November 2002, p. 112
} 
The use of vaccines is as prophylactic agents to prevent people catching the infection. Sokhey also looked for curative agents for plague. In this context chemical drugs (chemotherapy) and antisera were studied. The Institute examined different sulpha drugs and antibiotics. Earlier buffaloes were used for preparing antiplague serum; Sokhey successfully tried employing horses instead.

The techniques Sokhey worked out in connection with studies on plague vaccine were extended to cholera vaccine also. The cholera vaccine prepared in the liquid medium was found to be efficacious and was so prepared in large quantities and supplied.

There was installed the first molecular distillation unit in the country to separate vitamin A from shark liver oil.

In collaboration with Serum Department there was production of an effective polyvalent antivenin which provided protection against not only snake cobra, but also bite by Russells viper, echis or krait.

The particulars of Sokhey's scientific work appeared in the Annual Reports of the Institute . $^{8}$ He did not care much for publishing his research papers. Only in later years he wrote his papers. As such list of his publications is not long. The papers he contributed are listed in his memoirs (Ganapathi, 1976, pp.134-153).

Sokhey's retirement was due in 1947 but he received two years extension and laid down his office in 1949. He became the longest serving Haffkine Institute Director. During his tenure there was unprecedented expansion of the Institute. Under his leadership the Institute developed to become a well-known medical research institution with international reputation. It was one of the best equipped scientific institutions in the country.
On retirement from the Haffkine Institute, Sir Sahib Singh Sokhey accepted to work with the World Health Organization as Assistant Director General (Indian Medical Gazette, 1950). He operated as a senior officer at the WHO secretariat at Geneva. He held the office for three years. ${ }^{3}$ He looked after the Department of Central Technical Services. He was associated with WHO Expert Committee on Cholera (WHO, 1952). The Committee noting the outstanding qualities of his biologically standardized casein hydrolysate vaccine (Sokhey and Habbu, 1950, p. 33; pp.4353) recommended large-scale field-studies to determine its suitability for clinical use.

While working with the WHO at Geneva, the role he played in facilitating establishment of the Hindustan Antibiotics at Pimpri is covered in the following section.

\section{Crusader for Public Sector Drug Production and Patent Act Revision}

Sahib Singh Sokhey had his own considered views on the issue of drug production in India. This comes out from what he stated while inaugurating the Second Indian Pharmaceutical Conference held at Baroda in January 1942 (Sokhey, 1942, pp.15-25). He felt that an adequate production of drugs in the country itself was a must. He said that 'We must be prepared to build slowly but we must make no compromises.' 'We must make an effort to make ourselves selfsufficient at least as regards the essential drugs.' 'There is no doubt that the future lies with chemistry.' '....one essential for the production of drugs is the development of heavy chemical industry and production of fine chemicals in the country.' 'We cannot be usefully talking about the production of drugs without paying attention to our primary need of a well organized chemical industry.' He considered sale of patent and proprietary medicines to be 'a harmful and vicious

\footnotetext{
${ }^{8}$ K. Ganapathi, "Sahib Singh Sokhey, As I knew him,” Platinum Jubilee Commemoration Volume, Haffkine Institute $1899-1974$. Selected pages supplied by Dr S. M. Sapatnekar, Director of the Institute through his letter of 1 November 2002, pp 20-28
} 
trade.' 'The evil in India is growing apace. The only practical way to meet this menace is to enact a suitable effective legislation.'

In 1945 the Government of India appointed a Panel on Fine Chemicals, Drugs and Pharmaceuticals under the chairmanship of Sir Ram Nath Chopra to make recommendations regarding development of the industries (Report of the Panel on Fine Chemicals, Drugs and Pharmaceuticals, 1947, p. 94). As we mention later possibly the initial suggestion leading to formation for the Panel came from Sokhey. Sokhey was a senior member of the Panel; among the other 13-member panel were Dr K. A. Hamied, M. B. Amin, Dr B. C. Guha and Dr K. Ganapathi. Lt. Col. Sokhey provided notes on manufacture of vaccines, anti-toxins and sera; he together with Dr K. Ganapathi furnished comprehensive notes on the manufacture in India of sulpha drugs, mepacrine (atebrin), penicillin, and of vitamin A concentrate from shark liver oil, which were recorded in several of the appendixes to the report. In the Panel Report (1947) it was recommended that the country must produce all essential drugs and make them available for use of the masses at economical prices. The Panel considered that it should be the object to make India self-sufficient in regard to fine chemicals, drugs and pharmaceuticals within the next 15 years. It was noted that most of the processes for the manufacture of drugs and fine chemicals urgently needed for the country were covered by foreign patents. Under the existing Patents Act it was practically impossible to obtain compulsory license from a foreign patentee. The Panel suggested that Sections 22 and 23 of present Patents Act should be revised. It appears that in overall the recommendations of the Panel were in consonance with the Sokhey's way of thinking on the subject.

In 1953, the Government of India constituted Pharmaceutical Enquiry Committee
(Chairman: Major-General S. L. Bhatia) to make comprehensive enquiry into the working of the Pharmaceutical Industry as a preliminary to considering what steps the Government should take to establish it on sound lines. The Committee took note of the recommendation of the above Panel on the Fine Chemicals, Drugs and Pharmaceuticals. After elaborate studies the Committee in its Report (Report of the Pharmaceutical Enquiry Committee 1954, p. 402) made cogent recommendations with respect to scope and development of pharmaceutical industry. Regarding patenting the Committee viewed that the Patent Laws of the country should be amended to secure effective utilization of all developments in the field of science and medicine, wherever necessary in the interest of the country.

In the Report a reference was made to the Haffkine Institute, a governmental institution, engaging in production of vaccines and sera, undertaking semi-commercial manufacture of sulphathiazole in 1948. A mention was made of the Government of India deputing technical teams headed by S. S. Sokhey to visit the factories abroad in 1946 and 1948, to explore possibilities of manufacture of penicillin and other drugs. Subsequently there followed the establishment of Hindustan Antibiotics Limited, a Government of India Undertaking.

While collecting source material on Sokhey, I wrote to the Wellcome Library, London, in addition to several other institutions. The Wellcome drew my attention to Dr Sokhey's book The Indian drug industry and its future (New Delhi, S. S. Sokhey, 1959) ${ }^{9}$. I could not lay my hands on the book but came across his write-up, also of the year 1959, (Sokhey, 1959, pp.231-234) which covered what Maj. Gen. Sokhey said as the chairman of the panel discussion on "Discovery, Evaluation and Production of Drugs" held during the Eleventh Session of the Indian Pharmaceutical Congress at Lucknow (January 1959). I have made

\footnotetext{
${ }_{9}$ Petr Hons, Library Assistant, User Services; his letter of 29 April 2008
} 
liberal use of selected extracts from the publication to bring out the pioneering role, nothing less than crusade, General Sokhey had in stressing the drug manufacture under the public sector; I have chosen not to paraphrase the matter afresh in my own way but to reproduce what Sokhey put in his own words:

“.... During my association with the Haffkine Institute, Bombay, where I could provide the necessary facilities young chemical talent showed that what it can do. A group of young scientists under the leadership of Dr K. Ganapathi, developed during the war original large scale technical methods for the synthesis of sulphathiazole, suphadiazine, sulphamerazine, the then recently discovered wonder drugs. They also prepared some of the antimalarials like paludrine and chloroquin, and produced penicillin by the surface growth method. They designed and put up the first pilot chemical plant in the country for the manufacture of drugs on a semi-commercial scale.....

"Let me give you a brief account of the efforts that have been made to make the country self-sufficient in drugs. On the basis of the work done at the Haffkine Institute, I submitted in 1943 a scheme to the Government of India for this purpose. The Planning Department formed a Panel for Drugs and Fine Chemicals. As a result of their recommendations I and Dr Ganapathi were deputed abroad to prepare concrete proposals for putting up State plants for the manufacture of antibiotics and some of the synthetic drugs. We spent six months abroad and visited drug plants in Western Europe, Canada and United States, and also spent two months in the Penicillin Plant of the Toronto University where we learnt technology of the production of penicillin by deep fermentation process. On our return we submitted a detailed project for the production of penicillin, sulphonamides and antimalarial drugs.

“..... The scheme was approved by the Cabinet, but for the reasons too long to go into here, it was not implemented. We were, therefore, deputed again in 1948 to bring our scheme up-todate.

"We again visited different Western European countries and U.S.A. and brought the scheme up to the minute. We submitted a fresh project report complete with technical data, flow sheets and blue prints, and completely worked out capital and running costs. Again the project was approved by the Cabinet and again it was not implemented. Ultimately when I was appointed Assistant Director General of the World Health Organization, Geneva, I passed on the project report to this Organization and opened a department there, to help member nations to put up their own antibiotic plants. Eventually Hindustan Antibiotics was built, with the assistance of the World Health Organization and the UNICEF, from the data contained in our project report submitted to the Government in 1948. The building of this plant bore out our assertion that this job could be done much cheaper without the assistance of commercial firms.

"With this background of experience of the attitude of European and American firms, I happened to go to the Soviet Union in 1953. I was surprised to find that they took a totally different point of view; they treated applied technology on par with pure science. They were observing no secrecy regarding the know-how of drug manufacture, and I could easily enter the Soviet plant and learn all that I wanted ...........

"This experience gave me a new idea as to how to set up the drug industry in our country quickly and inexpensively. I conveyed my experience to Government, and I went back to the Soviet Union early in 1955 with chemist colleagues, Dr Ganapathi and Dr Shirsat. We spent three months in the Soviet Union, visited a large number of plants, and prepared, with the assistance of Soviet authorities, a project report for organizing the necessary plants needed for the 
manufacture of synthetic drugs, and antibiotics with the necessary basic and intermediate chemicals. The report indicated the costs involved and the aid that the Soviet Union would be agreeable to give.

"When the report was submitted to Government they found it so attractive that they asked the Soviet Union to send a team of experts to survey the Indian Pharmaceutical industry and make recommendations for putting up plants to make India self-sufficient in drugs. This Soviet team came in early 1956......" (Sokhey, 1959, pp. 231-234).

A reference may also be made to well documented coverage on dilemmas attendant on initiating drug production in India, in which the role played by Sokhey in establishment of public sector undertakings has been brought out (Tyabji, 2010. p 26).

The above in short is the background of how the beginning made through initiation and follow-up by General Sokhey, the stage was reached ultimately leading to the formation of the public sector undertaking the Indian Drugs and Pharmaceuticals Limited in 1961. Through the Russian collaboration in due course there were established Antibiotics Plant at Virbhadra (Rishikesh), Synthetic Drugs Plant at Hyderabad and Surgical Instruments Plant at Madras.

This is what Dr Nitya Anand said about Sokhey in the Gen. S. S. Sokhey Memorial Lecture he delivered at New Delhi in May 1977: (Anand, 1977. p 18). "His role in the creation of Hindustan Antibiotics Limited, Hindustan Insecticides Limited and the Indian Drugs \& Pharmaceuticals Limited, cannot be overemphasized - he was indeed the father of public sector drug industry."

Gen. Sokhey was also very clear about the need for revision of patent laws to enable the Indian drug industry to progress. This is how Sokhey thought on the subject as expressed in his 1959 lecture, “At present, as you know, almost hundred percent of the patents covering processes of manufacture of all essentials drugs are owned by foreign firms. These firms are neither producing the drugs in the country nor would they allow us to manufacture them on reasonable terms. We must realize that we are a free people now and we can abrogate these patents if we think it is necessary to do so in the interests of our people, and abrogate them we must if we are to develop our drug industry or in fact any industry. Whenever our scientists make new discoveries we can honour their efforts by awarding handsome money prizes. That would be a much better procedure than adherence to patent laws which do not benefit the real inventors (Sokhey, 1959, pp.231-234).”

It was "With his characteristic zeal he mobilized public opinion for the tactical modification of the patent laws in respect of drugs, if not their complete abrogation. The present modified Patent Act is the result of Gen. Sokhey's efforts and the national sector of the pharmaceutical industry has every reason to be grateful to him (Anand, 1977, p 18)."

On India becoming independent we inherited the Patents and Design Act 1911. This provided product patents for pharmaceuticals with 14 years period protection. This situation changed with promulgation of the Patents Act 1970. The statute provided for only process patent to be granted for chemicals, pharmaceuticals and foods, with a 5/7 year protection period, and License of Right after 3 years of granting the patent.

The developments of the early decades after independence, as covered above in brief, when Gen. Sokhey as an individual had a dominant role in creating awareness for much needed changes which followed, bringing great upsurge in the industry. In due course the Indian industry got to be counted among the top producers of drugs and pharmaceuticals of the world. The drug industry developed a confidence to face the compulsions of today's world of interdependence 
and acquit well as a member of the World Trade Organization (WTO). For the drug industry to reach the present stage, the contributions made by Sir Sokhey at right time shall stay as a permanent memorial in the pharmaceutical annals of the country.

\section{Creator of Drug Testing Facilities}

Sir Sahib Singh Sokhey was a visionary. The Drug Act 1940 had been passed but several formalities were to be gone through for appropriate structuring the system before provisions of the Act could come into actual force, and that was to take many years. While referring to the Drugs Act, Sokhey in his inaugural address at the Indian Pharmaceutical Conference in January 1942 stated that 'a legislation of this kind can be effective only if it is backed by adequate number of testing laboratories. I, therefore, hope that the Provincial Governments will establish before long properly equipped and staffed laboratories to carry out analytical work needed for enforcing the law .... ..... (Sokhey, 1942, pp. 15-25)'. It appears that broadly he was thinking of creation of appropriate drug control setups at state level. He thought of doing something on his own in this context as Director of the Haffkine Institute.

Col. Sokhey decided to develop drug testing facilities in the Department of Pharmacology of the Institute which at the time was being taken care of by B. V. Patel as Assistant Director. In the words of Patel, 'Soon after the enactment of the Drugs Act, 1940, Colonel Sokhey visualized the importance of a testing laboratory and role of inspectors for exercising quality control on drugs. It is with this in mind that he planned the expansion of the Department of Pharmacology, getting sanction of an additional floor for increased testing facilities ${ }^{10}$.' Drug Testing Section was started which later became official testing laboratory from April 1947, with B. V. Patel as the Government Analyst. Patel left the Institute in June 1949 to take charge of the post of Drugs Controller for the State of Bombay. Later Patel said that "All the training that I received in the Haffkine Institute helped me greatly in the work of drugs control and in organizing the new Drug Testing Laboratory at Baroda (see footnote 10)."

By the time Patel left the Haffkine Institute he had laid down a firm foundation of the Drugs Testing Section. In later years R. G. Tamhane who had been working in the Department of Pharmacology for several years became Senior Scientific Officer and Government Analyst ${ }^{11}$. Subsequently the Haffkine Institute Reorganization Committee decided to move the Drugs Testing Unit from the Department of Pharmacology, so that an independent Drugs Testing Laboratory he established for the Government of Maharashtra. Tamhane was transferred to the Drugs Control Department to organize the Laboratory.

Farsighted Col. Sokhey made a beginning by setting up drug testing facilities at the Haffkine Institute, ultimately leading to institution of drugs testing laboratories in the state of Bombay/ Maharashtra and Gujarat state on reorganization of the parent state, ahead of the other states. B. V. Patel groomed by Sokhey progressed and became recognized as a pioneer and leading light of drugs control in the country.

\section{EPILOGUe}

Several other aspects pertaining to Sokhey, professional and personal, are taken note of here.

\footnotetext{
${ }^{10}$ B. V. Patel, "Pharmacology and Research," Platinum Jubilee Commemoration Volume, Haffkine Institute 1899-1974. Selected pages supplied by Dr S. M. Sapatnekar, Director of the Institute through his letter of 1 November 2002 pp 134-135.

${ }^{11}$ R. G. Tamhane, "I learn about Drug Control," "Pharmacology and Research," Platinum Jubilee Commemoration Volume, Haffkine Institute 1899-1974. Selected pages supplied by Dr S. M. Sapatnekar, Director of the Institute through his letter of 1 November 2002, pp 139-141
} 
Sahib Singh was a government servant but he was courageous enough that during the colonial days he accepted Chairmanship of the Health Subcommittee of the National Planning Committee of the Indian National Congress, under the presidentship of Shri Subhash Chandra Bose (Ganapathi, 1976, pp.134-153).

It has been stated that General Sokhey's advice was often sought and highly valued by the Indian Council of Medical Research and the Council of Scientific and Industrial Research (Ahuja, 1971). No particular material has become available about Sokhey's advising the ICMR but the information on his working for the CSIR accessed is noted next.

On invitation from the Government of India Professor A. V. Hill, F.R.S., N.L., M.P., Secretary and official representative of the Royal Society, London, came to India in 1943 to discuss the organization of scientific and industrial research as a part of India's post-war reconstruction plan. In the valuable report submitted by Professor Hill there was made a most forceful plea for expansion and better coordination of research in India by liberal financial assistance from the Government. As a result there was appointed Industrial Research Planning Committee in early 1944. The Committee consisted of well known scientists and industrialists. $^{12}$

Sir R. K. Shammukham Chetty was Chairman of the Committee and among the nine members were Sir J. C. Ghosh, Lt. Col. S. S. Sokhey, Kasturbhai Lalbhai, Sir J. J. Ghandy, K. A. Hamied and Sir S. S. Bhatnagar. It was on recommendation of the Committee that establishment of more research laboratories under C.S.I.R. was taken in hand. The question of setting up the National Chemical Laboratory and National Physical Laboratory was examined (Ganapathi, 1976, 134-153).
Sokhey served as the Chairman of the Pharmaceutical and Drugs Committee of the Council of Scientific and Industrial Research. He was honorary advisor to Dr Hussain Zaheer, CSIR Director General. In 1965 he was appointed an Emeritus Scientist and now on he worked at the CSIR headquarters, residing at 31 Western Court.

Sokhey was a Foundation Fellow of the National Institute of Sciences (now Indian National Science Academy) and Indian Academy of Sciences, Bangalore. He became Vice-President (1948-49) of the former. He presided over Medical Section of the Indian Science Congress (1935).

In 1946 Lt. Col. Sokhey was knighted and in the same year he was made Major General. In 1947 he was awarded Lenin Peace Prize. He was honoured by the Government of India by nomination to the Rajya Sabha, in 1952.

Sokhey was closely associated with activities of the scientific workers and held the office of the President of the Scientific Workers Association. He was also President of the Indian Peace Council.

Sahib Singh married Leila Roy, a charming and highly cultured lady, who was a renowned dancer, performing under the stage name of Menaka. She was highly accomplished in the Kathak and Manipuri style of dancing. She ran a dancing school and invariably toured Europe every year to perform. They were a happy couple, but unfortunately she passed away in 1947; they had no children.

While in Britain during early part of his life Sahib Singh Sokhey was much influenced with the progressive intellectual tradition. 'Sokhey was a rationalist of an uncompromising and aggressive type ...... He knew and read a lot of politics and economics; here he was a confirmed radical subscribing to 'leftist' ideologies. He visited China and was very much impressed. He did not conceal

\footnotetext{
${ }^{12}$ Council of Scientific and Industrial Research, A Review by Director, Scientific and Industrial Research, January 1948, pp 204208
} 
his views and held them when it was dangerous to do so . . . . . . He had studied the literature so well and had such a fund of facts at his finger tips that few could argue with him and score over him. He was a great champion of the Public Sector . . . .....' (Ganapathi, 1976, 134-153).

Here I may also make a reference to what I came across in the papers received from the Rockefeller Foundation. I may reproduce the relevant paragraph which though not written in a complimentary tone, brings out the depth of nationalistic spirit which Sokhey possessed. Dr Hackett an expert from the Foundation visited the Haffkine Institute in 1928 when Dr Sokhey was officiating as Director. This is what he wrote in his diary:

"Sokhey was so much occupied with the social and political problems of India that it was difficult to hold him on the scientific plane. He was seething with indignation against Miss Mayo and her book, and was strong for absolute Indian independence and very anti-British. He told me that he read American literature by preference, which turned out to consist of books of Mencken and the 'American Mercury.' This mental attitude on Sokhey's part may explain to some extent the damaging criticism of his work in British circles wherever Sokhey is known." 1314

Sokhey had great interest in art, music, painting etc. ...... He had expert knowledge of Ajanta and Ellora and other art treasures. He said that he did not understand modern art (Ganapathi, 1976, 134-153).

In closing years of life, Sokhey was very lonely. The persons whom he had known very well were nowhere on the scene. His eye sight started failing him. He could not read. He had undergone a major operation. He lived in isolation.

Major General Sir Sahib Singh Sokhey passed away on 23 December 1971.

\section{BIBLIOGRAPHY}

Ahuja, M. L. Obituary, Indian Journal of Medical Research, 59 (1971): vii-viii.

Anand, Nitya. Challenges Facing the Indian Pharmaceutical Industry, S. S. Sokhey Memorial Lecture, 11 May 1977. p. 18.

British Medical Journal, 1 (1930):616.

Council of Scientific and Industrial Research, A Review by Director, Scientific and Industrial Research, January 1948, pp 204-208.

Ganapathi, K. Sahib Singh Sokhey, Biographical Memoirs of Fellows of the Indian National Science Academy, 4 (1976):134-153.

Indian Medical Gazette, 85 (1950):70

Report of the Panel on Fine Chemicals, Drugs and Pharmaceuticals, Department of Industries and Supplies, Government of India Press, Simla, 1947, p. 94.

Report of the Pharmaceutical Enquiry Committee, Ministry of Commerce \& Industry, Government of India, 1954, p. 402.

Sokhey, S. S. and Habbu, M. K. Casein Hydrolysate Cholera Vaccine, Bulletin of the World Health Organization, 3 (1950):33.

Sokhey, S. S. and Habbu, M. K. Biological Assay of Cholera Vaccine, Bulletin of the World Health Organization, 3 (1950):43-53.

Sokhey, S. S. Pharmaceutical Problems of India, Indian Journal of Pharmacy, 4 (1942):15-25.

Sokhey, S. S. The Production of Pharmaceuticals in the Country, Indian Journal of Pharmacy, 21 (1959):231234.

Tyabji, Nasir. Aligning with both Soviet Union and with the Pharmaceutical Transnationals, ISID Working Paper 2010/08, Institute for Studies in Industrial Development, New Delhi, August 2010. p. 26.

World Health Organization Technical Report Services No. 52, May 1952, p 18.

\footnotetext{
${ }^{13}$ Rockefeller Foundation Collection, Record Groups 6.1, Rockefeller Archive Center, Sleepy Hollow, NY; on correspondence with Bethany J. Antos, Archivist \& Internship Program Coordinator, through Dr Pardeep Gupta of the USciences, some useful material has been obtained on Sokhey, Diary of Dr Hackett, entry dated 23 December 1928, Bombay

${ }^{14}$ Mencken, Henry Louis (1880-1956) was a noted American newspaperman, editor and writer. He authored American Mercury, which became known for its 'debunking' articles.
} 